\title{
PENGGUNAAN INSEKTISIDA BOTANIS UNTUK MENGENDALIKAN HAMA PADA TANAMAN TOMAT
}

\author{
USE BOTANIS INSECTICIDE FOR TOMATO PEST CONTROL
}

\author{
Caroulus Simbalis Rante, Dantje T. Sembel, Elisabet R. Merlyn Meray, \\ Max Marthen Ratulangi, Moulwy F. Dien, dan Daisy S. Kandowangko*) \\ *)Jurusan Hama dan Penyakit, Fakultas Pertanian Unsrat Manado 95115 \\ e-mail royfdien@yahoo.com
}

\begin{abstract}
The experiment was conducted in the village of Touure, Tompaso District, Minahasa regency since April to August 2013. Designed studies using randomized block design with 3 treatments, namely fruit extract Bitung (treatment A), tuba root extract (treatment $B$ ) and water (control treatment), each treatment was repeated 3 times. Results showed that that the extract of Barringtonia asiatica and Derris elliptica has a botanical insecticide to control the properties of $N$. tenuis. Applications $B$. asiatica extract and $D$. elliptica were not significantly different, but both are significantly different from controls. In addition to $N$. tenuis found several Plant Pest Organisms (OPT) that attack tomato plants including pest Liriomyza sp., leafhoppers tomatoes., black stem base diseases, leaf spot diseases and viral diseases.
\end{abstract}

Key words : Botanic Insecticide, Tomato pest control

\section{ABSTRAK}

Penelitian dilaksanakan di Desa Toure, Kecamatan Tompaso, Kabupaten Minahasa sejak bulan April sampai dengan Agustus 2013. Penelitian dirancang menggunakan Rancangan Acak Kelompok dengan 3 perlakuan yaitu ekstrak buah bitung (perlakuan A), ekstrak akar tuba (perlakuan B) dan air (perlakuan kontrol) yang masing-masing perlakuan diulang sebanyak 3 kali. Hasil penelitian menunjukkan bahwa bahwa ekstrak Barringtonia asiatica dan Derris elliptica memiliki sifat insektisida botanis untuk mengendalikan $N$. tenuis. Aplikasi ekstrak $B$. asiatica dan $D$. elliptica tidak berbeda nyata, namun keduanya berbeda nyata dengan kontrol. Selain $N$. tenuis ditemukan juga beberapa Organisme Pengganggu Tanaman (OPT) yang menyerang tanaman tomat diantaranya hama Liriomyza sp., wereng tomat., penyakit pangkal batang hitam, penyakit bercak daun dan penyakit virus.

Kata kunci : Insektisida botanis, pengendalian hama tanaman tomat

Eugenia Volume 19 No. 2 Agustus 2013 


\section{PENDAHULUAN}

Di Sulawesi Utara, tanaman tomat merupakan komponen penting dalam susunan menu sehari-hari, diantaranya sebagai bahan baku untuk sayuran tumis, saos tomat, juice tomat, buah meja, serta sebagai bumbu ikan dan daging. Beberapa varietas tomat yang dibudidayakan oleh petani adalah tomat apel, tomat kentang, tomat biasa, tomat cherry, dan tomat keriting. Luas areal penanaman tomat di Sulawesi Utara sampai dengan Maret 2010 adalah 2613 ha dengan produksi antara 40-60 ton per ha (Dinas Pertanian Pangan dan Hortikultura, Sulawesi Utara, 2010).

Budidaya tomat khususnya di Desa Toure Kecamatan Tompaso Kabupaten Minahasa telah dilakukan sejak zaman colonial. Upaya untuk meningkatkan produksi tomat di daerah ini mengalami kendala yaitu adanya serangan organisme pengganggu tanaman (OPT). Serangan OPT dapat menyebabkan penurunan kualitas maupun kuantitas produksi, yang secara langsung mempengaruhi pendapatan petani.

Nesiodiocoris tenuis adalah serangga yang baru ditemukan pada tanaman tomat. Menurut Shepard, dkk. (1999), serangga ini dilaporkan menyerang bunga dan buah tomat di Jawa dan juga bersifat sebagai predator terhadap kutu daun yang menyerang tanaman tomat.

Budiman dkk. (2010) melaporkan bahwa proses kopulasi $N$. tenuis terjadi pada pagi hari dan sore hari selama antara $30-60$ menit. Kopulasi diawali dengan tindakan kejar mengejar, saling bersinggungan satu dengan yang lain. Serangga jantan aktif berputar-putar mengitari betina kemudian terjadi kopulasi dengan posisi tubuh saling berbalik. Selama berlangsungnya proses kopulasi terlihat kedua serangga (jantan dan betina) berdiam diri.

Gejala serangan yang terlihat pada bagian tangkai atau batang yang dihisap yakni berwarna kecoklatan, sedangkan bila menyerang bunga maka bunga tanaman tomat tersebut mudah patah atau cepat jatuh. Dengan demikian serangan $N$. tenuis dapat mengganggu reproduksi dan perkembangan buah tomat (Shepard, dkk. 1999; Olsen, 2008; Pytaa, 2011).
Nimfa dan imago mengisap cairan tanaman pada pangkal tangkai bunga secara melingkar sehingga menimbulkan gejala berupa bintik-bintik hitam yang melingkar pada tangkai bunga (Anonim, 2010).

Sanchez (2009) melaporkan bahwa $N$. tenuis merupakan serangga hama baik nimfa maupun imago yang memiliki potensi merusak dan menggagalkan panen pada tanaman tomat. Hasil penelitian (Dien dan Rante, 2011) menunjukkan bahwa Tingkat serangan $N$. tenuis pada tanaman tomat di Sulawesi Utara mencapai 28,46 \%$57,63 \%$.

Pentingnya $N$. tenuis sebagai hama perlu diwaspadai karena pada serangan berat tanaman akan mengalami gagal panen. Berbagai cara pengendalian hama dapat dilakukan, namun harus mempertimbangkan dampak residu terhadap konsumen, lingkungan, dan terhadap mahluk hidup lainnya. Pertanian organik merupakan alternatif pengendalian yang ramah lingkungan. Salah satu komponen dalam pertanian organik adalah pemanfaatan pestisida nabati untuk mengendalikan hama.

Pestisida nabati adalah pestisida yang bahan dasarnya diperoleh dari tanaman dan dapat dibuat dengan teknologi sederhana yang dikerjakan oleh kelompok tani atau petani perorangan. Pestisida nabati dibuat berupa larutan, hasil perasan, rendaman, ekstrak hasil olahan bagian tanaman, seperti daun, batang, akar, dan buah (Novizan, 2002; Sarjan, 2012).

Barringtonia asiatica dan Derris elliptica adalah jenis tumbuhan yang dapat digunakan sebagai pestisida nabati. Hasil beberapa penelitian menunjukkan bahwa ekstrak biji buah $B$. asiatica mampu menghambat pertumbuhan larva Crucila trifenestrata sebesar $35 \%$ dan mampu mempengaruhi fekunditas (produksi telur) serangga sekitar $60 \%$. Tepung biji Bitung yang dicampurkan ke dalam tepung terigu pada konsentrasi 10\% mampu menolak populasi serangga Sitophilus oryzae sampai dengan $80 \%$ dan membunuh $60 \%$ populasi serangga S. oryzae (Anonim, 2012).

D. elliptica atau racun tuba dimanfaatkan pula sebagai insektisida untuk mengatasi kutu dan ulat yang menjadi hama di perkebunan. Tanaman 
tuba yang sangat beracun bagi serangga adalah pada bagian akar. Akar ditumbuk dan dilarutkan dalam air. Larutan tuba ini lah yang digunakan sebagai bahan aktif pestisda nabati. Racun akar tuba dulu dikenal dengan nama derris, sekarang lebih dikenal dengan rotenone. Selain rotenone, tuba juga mengandung racun deguelin, racun tephorsin, dan racun toxicarol (Anonim, 2010a).

Penelitian bertujuan untuk mengetahui efektifitas ekstrak buah bitung ( $B$. asiatica) dan ekstrak akar tuba ( $D$. elliptica) untuk mengendalikan hama $N$. tenuis pada tanaman tomat. Hasil penelitian diharapkan dapat digunakan sebagai masukan dalam program pengendalian hama yang ramah lingkungan khususnya pada hama $\mathrm{N}$. tenuis di masa yang akan datang.

\section{METODE PENELITIAN}

Penelitian dilakukan di Desa Toure, Kecamatan Tompaso, Kabupaten Minahasa selama 5 bulan. Penelitian dirancang menggunakan Rancangan Acak Kelompok dengan 3 perlakuan yaitu ekstrak buah bitung (perlakuan A), ekstrak akar tuba (perlakuan B) dan air (perlakuan kontrol) yang masing-masing perlakuan diulang sebanyak 3 kali.

Pembuatan ekstrak buah bitung dilakukan dengan membelah dan mengambil bagian daging dari biji buah bitung, kemudian dibersihkan dengan air. Daging biji buah bitung dipotong-potong dan ditimbang sebanyak 1.000 gram, dihancurkan (blender) di dalam $1.000 \mathrm{ml}$ aquades, kemudian diperas sehingga diperoleh ekstrak yang berwarna putih susu.

Pembuatan ekstrak akar tuba dilakukan dengan membersihkan akar tuba dengan air kemudian dipotong kecil-kecil. Potongan akar tuba ditimbang sebanyak $1.000 \mathrm{gr}$ dihancurkan (blender) di dalam $1.000 \mathrm{ml}$ aquades, kemudian disaring sehingga diperoleh ekstrak yang berwarna coklat keruh.

Aplikasi masing-masing perlakuan dilakukan setiap dua minggu sekali dengan konsentrasi $10 \%$. Penyemprotan tanaman dilakukan pada sore hari dengan menggunakan hand-sprayer.

\section{HASIL DAN PEMBAHASAN}

Rata-rata persentase bunga terserang Nesidiocoris tenuis bervariasi yakni pada perlakuan A (ekstrak Barringtonia asiatica) sebesar 52,79\%, perlakuan B (ekstrak Derris elliptica) sebesar $53,31 \%$, dan perlakuan C (Kontrol) sebesar $81,81 \%$, seperti terlihat pada Tabel 1 .

Tabel 1. Rata-rata Persentase Bunga Tomat Terserang Nesidiocoris tenuis

(Table 1. The Average Percentage of Attacks N. tenuis in Tomato Plants Flower)

\begin{tabular}{llcc}
\hline \multicolumn{1}{c}{ Perlakuan } & Persentase Serangan (\%) & Notation \\
\hline A. & Barringtonia & 52.79 & $\mathrm{a}$ \\
B. & Derris & 53.31 & $\mathrm{a}$ \\
C. & Control & 81.81 & $\mathrm{~b}$ \\
\hline
\end{tabular}

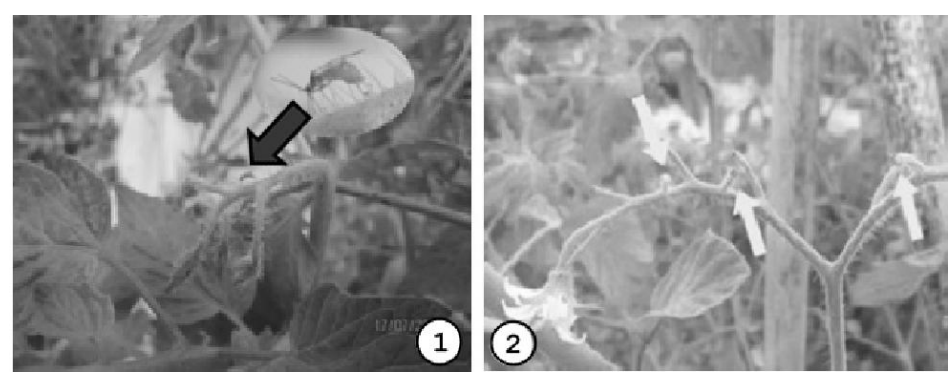

Gambar 1. Nesidiocoris tenuis (Figure 1. Nesidiocoris tenuis)

Gambar 2. Gejala Serangan N. Tenuis (Figure 2. Symptoms of N. tenuis) 
Hasil analisis menunjukkan bahwa aplikasi ekstrak Barringtonia asiatica dan Derris elliptica tidak berbeda nyata, namun keduanya berbeda nyata dengan control. Tingginya serangan hama $N$. tenuis diduga karena intensitas aplikasi perlakuan yang rendah. Penyemprotan $B$. asiatica dan $D$. elliptica pada tanaman tomat hanya dilakukan 2 minggu sekali yakni pada tanggal 29 Juni, 13 Juli, dan 27 Juli 2013. Peningkatan intensitas pengendalian seharusnya dilakukan terutama pada saat tanaman mulai mengeluarkan bunga.

Nimfa dan imago mengisap cairan tanaman pada pangkal tangkai bunga secara melingkar sehingga menimbulkan gejala berupa bintik-bintik hitam yang melingkar pada tangkai bunga (Anonim, 2010). Selanjutnya Sanchez (2009), melaporkan bahwa $N$. tenuis merupakan serangga hama baik nimfa maupun imago yang memiliki potensi merusak dan menggagalkan panen pada tanaman tomat. Selain pada tanaman pokok, penyemprotan juga sebaiknya diarahkan pada gulma yang tumbuh di sekitar areal pertanaman. Sastrodihardjo (1979) menyatakan bahwa keberadaan gulma pada areal penanaman dapat mempengaruhi populasi serangga. Serangga dapat memanfaatkan gulma ataupun tanaman lainnya di sekitar areal penanaman untuk menghindari sinar matahari secara langsung, dan ataupun menghindari dari serangan predator.

Berdasarkan data persentase bunga terserang pada Tabel 1 dan dihubungkan dengan waktu aplikasi perlakuan, ternyata aplikasi $B$. asiatica dan $D$. elliptica pada 13 Juli dan 27 Juli menghasilkan penurunan serangan $\mathrm{N}$. tenuis (data 17 Juli dan 27 Juli 2013). Hal ini menunjukkan bahwa ekstrak $B$. asiatica dan $D$. elliptica memiliki sifat insektisida botanis untuk mengendalikan $N$. tenuis.

Insektisida botanis adalah jenis insektisida yang menggunakan bahan tumbuhan sebagai bahan dasarnya. Keuntungan penggunaan insektisida botanis antara lain adalah tidak mencemari lingkungan karena residunya relatif mudah terdegradasi. Disamping itu bahan baku insektisida botanis mudah didapatkan dan mudah diterapkan di lapangan. Insektisida botanis adalah produk yang berasal dari tumbuhan yang mempunyai kelompok metabolit sekunder yang mengandung berbagai senyawa bioaktif seperti alkaloid, terpenoid, saponin, fenolik dan zat kimia sekunder lainnya (Samsudin, 2008). Ekstrak metanol B. asiatica memperlihatkan aktivitas insektisida yang paling kuat dibanding ekstrak daun dan kulit batangnya (Anonim, 2012).

Selain $N$. tenuis ditemukan juga beberapa OPT yang menyerang tanaman tomat diantaranya hama Liriomyza sp., wereng tomat., penyakit pangkal batang hitam, penyakit bercak daun dan penyakit virus dengan persentase serangan yang beragam seperti terlihat pada Tabel 2 .

Melihat Tabel 2, persentase tanaman terserang penyakit pangkal batang hitam mencapai $53,24 \%$. Hasil isolasi dilaboratorium ternyata penyakit pangkal batang hitam disebabkan oleh jamur Colletotrichum sp. Patogen ini menyebabkan bagian pangkal batang menjadi hitam kemudian secara berangsur-angsur pangkal batang menjadi kecoklatan. Pada kondisi hujan dan lembab gejala serangan banyak ditemukan pada tanaman sampel.

Tabel 2. Persentase Tanaman Terserang OPT (Pengamatan Terhadap 534 Tanaman Sampel) (Table 2. The Percentage Infected of Organisms (Observations on 534 Plant Samples)

\begin{tabular}{lrrrr}
\hline \multicolumn{1}{c}{ Jenis OPT } & \multicolumn{2}{c}{ Rata-rata tanaman terserang } & Jumlah \\
& pada bedeng perlakuan & tunaman \\
& B. asiatica & D. eliptica & Kontrol & terserang \\
\hline Hama Liriomyza sp. & 0,74 & 1,31 & 2,24 & 4,30 \\
Hama wereng tomat & 0,93 & 0,56 & 1,12 & 2,61 \\
Penyakit virus tomat & 8,05 & 6,74 & 9,73 & 24,5 \\
Penyakit pangkal batang hitam & 16,67 & 14,91 & 21,66 & 53,24 \\
Penyakit bercak daun & 3,18 & 2,05 & 4,68 & 9,92 \\
\hline
\end{tabular}




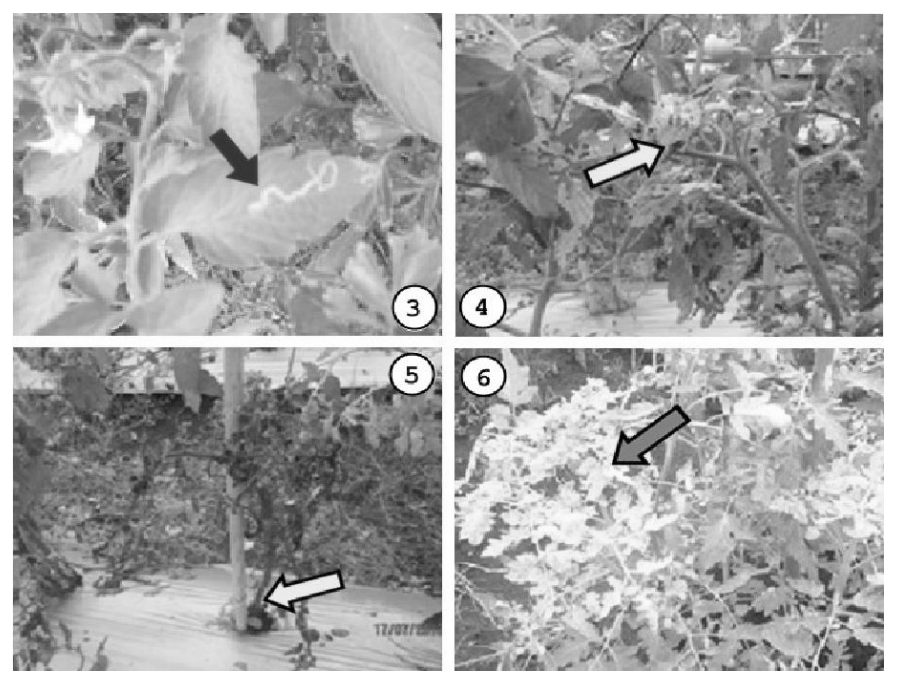

Gambar 3. Gejala Serangan Liriomyza sp. (Figure 3. Symptoms of. Liriomyza sp.)

Gambar 4. Gejala Serangan Penyakit Bercak Daun (Figure 4. Symptoms of Leaf Spot Desease)

Gambar 5. Gejala Serangan Penyakit Pangkal Batang Hitam (Figure 5. Symptoms of Black Stem Rot Disease) Gambar 6. Penyakit Virus Tomat (Figure 6. Symptoms of Tomato Virus Disease)

Hasil diskusi dengan peserta Internasional Conference, Biodiversity and Integrated Pest management (Field trip, 6 Juli 2013) menyatakan bahwa tanaman menunjukkan gejala bercak pada pangkal batang yang kemudian menjadi hitam dapat disebabkan karena kekurangan unsur Boron.

Boron merupakan unsur mikro yang dibutuhkan oleh tanaman. Fungsi boron dalam tanaman antara lain berperanan dalam metabolisme asam nukleat, karbohidrat, protein, fenol dan auksin. Kekurangan unsur Boron dapat menyebabkan pertumbuhan terhambat terutama pada jaringan meristematik (pucuk akar), mati pucuk (die back), mobilitas rendah, dan buah yang sedang berkembang menjadi sangat rentan terserang penyakit (Anonim, 2012a).

Kerusakan pada tanaman seringkali tidak hanya disebabkan oleh adanya serangan hama dan penyakit. Tidak jarang kematian tanaman disebabkan oleh faktor-faktor lingkungan seperti kelebihan atau kekurangan air, suhu yang terlalu ekstrim serta kelebihan atau kekurangan unsur hara mikro. Adanya kekurangan pada salah satu unsur mikro dapat juga menimbulkan kerusakan yang serius pada tanaman (Rachmaya, 2013).

Di dalam buah tomat, kekurangan boron belum mempunyai arti penting secara ekonomi.
Tanaman biasanya menunjukkan gejala awal berupa terdapatnya bercak berwarna hitam pada titik tumbuh batang. Tumbuhan akan terlihat kerdil, sedangkan pertumbuhan dari daun-daun baru menjadi lebih lambat daripada pertumbuhan batang. Cotyledon, atau bakal daun, dan daundaun muda dengan jelas akan berwarna ungu ketika tanaman masih muda. Batang menjadi kerdil dan tunas terminal pertumbuhannya akan terhambat, menguning dan mati. Karakteristik utama adalah kerapuhan pada petioles, atau ujung batang. Akar akan menunjukkan pertumbuhan yang sangat buruk dan akan berwarna coklat muda atau coklat. Buah kerap kali tertutup dengan warna gelap atau akan mengering (Anonim, 2011).

\section{KESIMPULAN}

Ekstrak buah Bitung (Barringtonia asiatica) dan akar deris (Derris elliptica) dapat digunakan sebagai insektisida botanis untuk mengendalikan hama Nesidiocoris tenuis.

Intensitas penyempotan (aplikasi) ekstrak buah bitung ( $B$. asiatica) dan akar deris (D. elliptica mempengaruhi serangan hama $N$. tenuis pada bunga tanaman tomat. 
Penyakit pangkal batang hitam merupakan patogen yang banyak ditemukan pada tanaman sampel.

\section{UCAPAN TERIMA KASIH}

Disampaikan terima kasih yang sebesarbesarnya kepada IPM-CRSP, USDA dan Clemson University SC, USA yang telah membiayai penelitian ini

\section{DAFTAR PUSTAKA}

Anonim, 2010. Species Nesidiocoris tenuis (Reuter, 1895) Tomato Mirid. Department of the Environment, Water, Heritage and the Arts. Canberra ACT 2601 Australia. http://www.environment.gov.au/biodiversity labrs/online-resources/fauna/afd/taxa/ e003f5bf-edd9-4be5-8354-0501 e0035f11

Anonim, 2010a. Tanaman Pestisida Nabati: Tuba alias Jenu alias Derris elliptica Bth. http://isroi.com/2010/08/01/tanamanpestisida-nabati-tuba-alis-jenu-derriselliptica-bth/

Anonim, 2011. Tanda kekurangan unsur hara dalam tanaman pangan. http://rindang codot.blogspot.com/2011/11/tandakekurangan-unsur-hara-dalam.html

Anonim, 2012. Barringtonia asiatica. From Wikipedia, the free encyclopedia. http://en.wikipedia.org/wiki/Barringtonia_as iatica

Anonim, 2012a. Tanda Tanaman Kelebihan dan Kekurangan Unsur Hara. http://tips petani. blogspot.com/2012/12/pertanda-tanamankelebihan-dan.html.

Budiman, A. A., D. T. Sembel., M. Tulung., V. Memah., M. Meray., M. Ratulangi., $H$. Hammig., G. Carner., dan M. Sheppard, 2010. Biologi dan Tingkat serangan Nesidiocoris tenuis Reuter pada Tanaman Tomat di Sulawesi Utara. Media Publikasi IImu Pertanian Eugenia Vol.16 No.1 April 2010. hal. 1-12.

Dien M. F dan C. S. Rante, 2011. Populasi dan Tingkat Serangan Nesidiocoris tenuis
Reuter (Hemiptera; Miridae) pada Tanaman Tomat Di Sulawesi Utara. Penelitian Kerjasama IPM-CRSP, USAID, dan Clemson University, SC, USA dengan Fakultas Pertanian Universitas Sam Ratulangi.

Novizan, 2002. Membuat dan Memanfaatkan Pestisida Ramah Lingkungan. Agromedia Pustaka. Jakarta.

Olsen C, 2008. Green Tobacco Capsid Nesidiocoris tenuis Reuter. http://www. invasive .org/browse/detail.cfm?imgnum $=5383543$

Pytaa E, 2011. Nesidiocoris tenuis. http://www.evira.fi/portal/fi/kasvit/viljely-ja tuomanto/kasvitaudit ja tuholaiset/muita kasvintuhoojia/nesidiocoris tenuis -lude/

Rachmaya, V. 2013. Mengenali gejala kekurangan unsure mikro pada tanaman perkebunan dan upaya penanganannya. http://vinarachmaya.wordpress.com/2013/ 04/20/mengenali-gejala-kekuranganunsur-mikro-pada-tanaman-perkebunandan-upaya-penanganannyal

Sanchez, J. A, 2009. Density thresholds for Nesidiocoris tenuis (Heteroptera: Miridae) in tomato crops. Journal of Biological Control, Volume 51 No.3. (493-498) December 2009

Samsudin, H. 2008. Pengendalian Hama Dengan Insektisida Botani. http:// www. pertanian sehat.or.id/index.php?pilih=news\&mod=ye s\&aksi $=$ lihat\&id $=20$

Sarjan M, 2012. Potensi Pemanfaatan Insektisida Nabati dalam Pengendalian Hama pada budidaya Sayuran Organik. Program Studi Hama dan Penyakit Tumbuhan. Fakultas Pertanian Universitas Mataram. http://saiful-mahdi.blogspot.com/2012/01/ potensi-pemanfaatan-insektisidanabati.html

Shepard, M., G. R. Carner., A. T. Barrion (H. C. Ooi and $H$. van den Berg, 1999). Insect and their natural enemies associated with vegetables and soybean in Southeast Asia. 
